\title{
Evaluation of the Duration of a Hiking Trip as a Kind of Test Within the All-Russian Physical Culture and Sports Training Program "Ready for Labor and Defense" Among Teenagers of the $6^{\text {th }}$ Age Group
}

\author{
Evgeniy A. Nikolaev, Nadezhda V. Surikova, \\ Elena D. Chuprova and Bulat B. Gomboev* \\ Siberian Federal University \\ Krasnoyarsk, Russian Federation
}

Received 26.10.2020, received in revised form 11.01.2021, accepted 08.02.2021

\begin{abstract}
The purpose is providing rationale for the distance duration $(15 \mathrm{~km})$ of the All-Russian physical culture and sports training program "Ready for Labor and Defense" hiking trip among young men $\left(6^{\text {th }}\right.$ stage).

The participants in this experiment were students $(n=16)$ aged 18-21. The following physiological methods were used: heart-rate monitoring, measurement of blood pressure and subsequent determination of cardiac output, recording and interpretation of electrocardiograms according to the method of professor A. Zavyalov, as well as mental state determination by means of the "Well-being, energies, mood" method.

Physical efficiency dynamics of teenagers by key indicators within the research at all keypoints does not reflect significant functional changes in the body that would let us state the accumulation of great fatigue $(\mathrm{ECG}=14 \pm 2.38$, WAM index was 5.2 at the beginning and 4.9 at the end, heart-rate $=97$ BPM).

The main indicators of the dynamic analysis of the functional state of participants within the hiking trips allows us to conclude that a distance of $15 \mathrm{~km}$ is optimal for teenage boys. However, variable conditions are possible for in the form of an increase in distance to 18 $\mathrm{km}$, final recommendations require additional research.
\end{abstract}

Keywords: hiking trip, functional state, functional index, physical activity, tiredness, students, optional tests, GTO program.

Research area: theory and methodology of physical education, sports training, healthimproving and adaptive physical culture.

(C) Siberian Federal University. All rights reserved

* Corresponding author E-mail address: enikolaevSFU@Gmail.com, poleva_n@list.ru, ed-chuprova@yandex.ru, bulat_gomboev@mail.ru

ORCID: 0000-0003-2967-3463 (Nikolaev); 0000-0002-6608-7802 (Surikova); 0000-0003-3783-7392 (Chuprova); 0000-0002-0124-5304 (Gomboev) 
Citation: Nikolaev, E.A., Surikova, N.V., Chuprova, E.D., Gomboev, B.B. (2021). Evaluation of the duration of a hiking trip as a kind of test within the all-russian physical culture and sports training program "Ready for Labor and Defense" among teenagers of the $6^{\text {th }}$ age group. J. Sib. Fed. Univ. Humanit. Soc. Sci., 14(2), 250-256. DOI: 10.17516/1997-1370-0716.

\title{
Оценка продолжительности дистанции туристского похода как вида испытания Всероссийского физкультурно-спортивного комплекса «Готов к труду и обороне» для юношей 6 ступени
}

\author{
Е.А. Николаев, Н.В. Сурикова, \\ Е.Д. Чупрова, Б.Б. Гомбоев \\ Сибирский федеральный университет \\ Российская Федерачия, Красноярск
}

\begin{abstract}
Аннотация. Цель работы - обоснование продолжительности дистанции (15 км) для туристского похода Всероссийского физкультурно-спортивного комплекса «Готов к труду и обороне» для юношей (6 ступень). В констатирующем эксперименте приняли участие студенты $(\mathrm{n}=16)$ в возрасте 18-21 года. Были использованы следующие физиологические методы: измерение частоты сердечных сокращений, измерение артериального давления с последующим определением систолического и минутного объема крови, регистрация электрокардиограммы и ее расшифровка по методике профессора А.И. Завьялова, а также определение психоэмоционального состояния по методике «Самочувствие, активность, настроение». Динамика физической работоспособности юношей по основным показателям проведенного исследования во всех контрольных точках не отражает значимых функциональных изменений в организме, которые позволили бы констатировать накопление большого утомления (ЭКГ $=14 \pm 2,38$ баллов, показатель САН составил 5,2 в начале дистанции и 4,9 - в конце, ЧССср=97 уд./мин). Анализ динамики основных показателей функционального состояния участников туристского похода позволил заключить, что дистанция в 15 км является оптимальной для юношей. Однако возможны вариативные условия в виде увеличения продолжительности дистанции до 18 км. Окончательные рекомендации требуют дополнительных исследований.
\end{abstract}

Ключевые слова: туристский поход, функциональное состояние, функциональные показатели, физическая нагрузка, утомление, студенты, испытания по выбору, комплекс «ГТО».

Научная специальность: 13.00.04 - теория и методика физического воспитания, спортивной тренировки, оздоровительной и адаптивной физической культуры.

\section{Introduction}

to the research problem

The All-Russian physical culture and sports training program «Ready for Labor and Defense» is a set of physical exercises aimed at evaluation of the population's readiness for labor and defense activities, as well as assessing the level of physical fitness, comprehensive and harmonious development of the individual and their physical health. 
Citizens of Russia, on the principles of voluntariness, are offered to perform from 4 to 9 types of physical tests, designed to assess the level of basic physical qualities development (speed, strength, stamina, flexibility, etc.). The standards of performing the GTO sports training program control exercises complex are divided into 11 age groups (from 6 to 70 years old and older). The age group considered in the research ( $6^{\text {th }}$ group) corresponds to the age group of 18-29 years.

Most of the tests of the GTO sports training program are characterized by the fulfillment of a motor action as a kind of sports discipline in a limited space (gym, pool, shooting range, stadium) with a small amount of time. A hiking trip, as a test of applied orientation, is a complex test that includes overcoming the walking distance and demonstrating the possession of special tourist knowledge, skills and abilities. In this regard, the system of organizing and conducting the «hiking trip» test requires a thorough scientific and methodological justification.

Conceptological foundations of the research (theoretical framework): the system of organizing and carrying out the All-Russian physical culture and sports program «Ready for work and defense» tests in modern conditions (Lubysheva, Roubaix, 2019; Uvarov, 2017); normative base of students' physical fitness (Matyunina, 2015); characteristic of a hiking trip as a test of the GTO sports program (Ginzhul, Kravchuk, 2018; Nikolaev et al., 2019; Nikolaev et al., 2020).

Statement of the problem. One of the problematic components of the «hiking trip» test is the pedestrian crossing distance length. At all stages of the GTO sports program, the length of the walking distance and the content of tourist skills were determined collectively by experts in the field of sports tourism. We are not aware of scientific experimental research in this area, which indicates the relevance of the scientific research organization within the walking distance duration for students. This opinion is confirmed by the statements of many authoritative experts who consider it necessary to conduct research on the scientific substantiation of the hiking trip as well as the content of tourist skills and abilities for various stages of the GTO program (Uvarov, 2017; Lubysheva, Roubaix, 2019; Nikolaev, 2019; Nikolaev, 2020).

Currently, in the regulations for the $6^{\text {th }}$ age group of the GTO program, the fulfillment of the type of tourism tests is formulated as follows: "A hiking trip with a test of tourist skills with a length of at least $15 \mathrm{~km}$ (number of points)». There are no other conditions for tourist readiness, and only in the «Methodological Recommendations for the Test Standards Organization and Implementation of the AllRussian Physical Culture and Sports Complex «Ready for Labor and Defense» (GTO)» (Approved by the Ministry of Sports of the Russian Federation on 01.02.2018) some conditions for the type of travel distances are indicated: "Compliance with the standards is carried out, as a rule, in the natural environment (if available, it is recommended to use the system of national and regional ecotourism trails); the nature of the route (trails, dirt roads, off-road, etc.), the presence and weight of a backpack are not regulated».

Purpose: Duration evaluation of a hiking trip as a kind of test within the All-Russian physical culture and sports training program «Ready for Labor and Defense» among teenagers of the $6^{\text {th }}$ age group.

\section{Methods}

The study was carried out in the form of an ascertaining experiment by Siberian Federal University Physical Culture Department. The study involved 1-3-year students (16 male students) of the main medical group. The students participating in the experimental hike were engaged in physical culture in the main educational department 2 times a week and neither had any special physical and technical readiness, nor were engaged in sports sections.

The distance of the hiking trip in accordance with the requirements of the GTO complex was $15 \mathrm{~km}$; the nature of the terrain is mediumrugged, in a wooded part, mainly along earthen paths; movement speed $-5 \mathrm{~km}$ per hour; route type - circular, start and finish in one place; the weight of personal equipment was calculated for participation in a one-day hiking trip (backpack not less than $5 \mathrm{~kg}$ ). 
To control the functional state of the participants, the following parameters were used: heart rate (HR), blood pressure (BP), changes in the electrocardiogram (ECG), psychoemotional state «Well-being, activity, mood» (WAM).

In recent years, methods for assessing the state of health and functional readiness based on the heart rhythm analysis have become widespread (Isaev, 2017).

One of the organs of the human body that limits physical performance is the heart. The most efficient, objective and accessible method for controlling the degree of myocardial fatigue in those engaged in physical exercises is the method of ECG registration, developed by A. I. Zavyalov.

The developed system of pedagogical control over the state of human fatigue based on changes in the ECG curve that occurs immediately at the time of exposure to physical activity includes 8 degrees of tiredness - 1) no tiredness; 2) slight tiredness; 3 ) moderate tiredness; 4) acute tiredness; 5) fatigue; 6) overfatigue; 7) pre-pathology; 8) overstrain. Each degree of tiredness corresponds to the intensity of the functioning of metabolism in the myocardium and reflects the body's response to the value, intensity of the impact of physical exercise ( $\mathrm{Za}$ vyalov, 1984).

The recording of participants' functional state indicators while overcoming the distance was carried out according to the following algorithm: 1) measurement of the initial functional indicators at the beginning of the hiking trip; 2) measurement of indicators every $3 \mathrm{~km}$ of the distance (one circle) after passing 3, 6, 9, 12 and 15 kilometers (there was no rest during the measurement of indicators, since no more than 1.5 minutes were allotted for this type of activity).

\section{Discussion}

In Fig. 1, on the basis of ECG data, the dynamics of students' tiredness is presented in the process of a $15 \mathrm{~km}$ hiking trip.

Before the start of the hiking trip, control myocardium functional state measurements were carried out, which made it possible to obtain initial data and ascertain the possibility of students' participation in the experiment. The resting points were $1.9 \pm 0.6$ points.

Thus, we can observe that the youngsters' tiredness degree control (Fig. 1) shows a significant increase in points relative to the rest at the first measurement point $-3 \mathrm{~km}$. In addition, the fulfillment of the entire motor action «hiking trip» in a given zone of physical load intensity corresponds to the criterion of absence of tiredness (see Table 1), since the value of physical activity points does not exceed 18 . Figure 1 demonstrates that male teenagers have good working capacity.

Determination of the differences' reliability in the tiredness degree indicators (Table 1) of male teenagers at the beginning $(1.9 \pm 0.6)$ and the end $(14 \pm 2.38)$ of the hiking trip allowed us to reflect a significant and reliable difference at $\mathrm{P}<0.001$.

Thus, according to the teenagers' tiredness dynamics chart during the hiking trip (Fig. 1), it is clear that the tiredness degree at points of the distance of $3 \mathrm{~km}, 6 \mathrm{~km}, 9 \mathrm{~km}, 12$ and $15 \mathrm{~km}$ does not have any significant differences. And, therefore, for male teenagers the distance covered is adequate and acceptable physical activity.

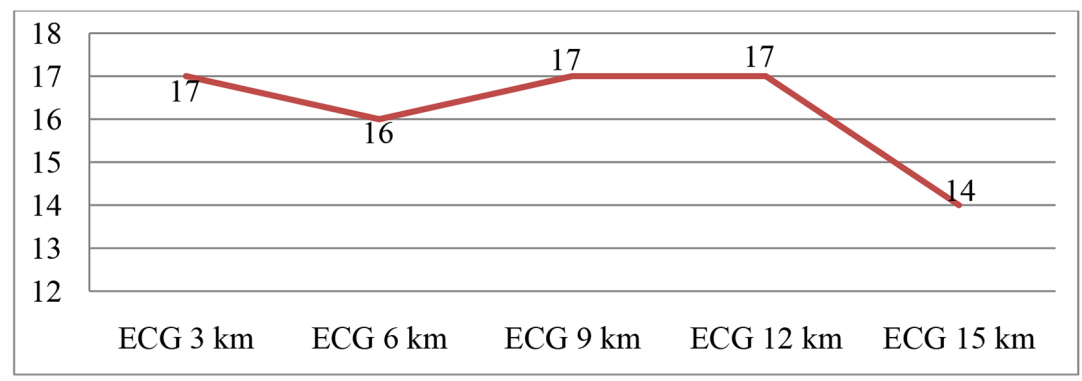

Fig. 1. Male teenagers tiredness dynamics in the process of a hiking trip $(15 \mathrm{~km})$ 
Evgeniy A. Nikolaev, Nadezhda V. Surikova... Evaluation of the Duration of a Hiking Trip as a Kind of Test Within...

Table 1. Male teenagers tiredness degree comparison during the hiking trip at the beginning and at the end

\begin{tabular}{|c|c|c|}
\hline \multirow{2}{*}{ Parameters } & \multicolumn{2}{|c|}{ Youngsters } \\
\cline { 2 - 3 } & Before & After \\
\hline HSR & 1.9 & 14 \\
\hline $\mathrm{m}$ & 0.6 & 2.38 \\
\hline $\mathrm{T}$ & \multicolumn{2}{|c|}{4.925} \\
\hline $\mathrm{P}$ & $\mathrm{P}<0.001$ \\
\hline
\end{tabular}

Simultaneously with the study of physical tiredness (by means of the ECG control method), the change in the psychoemotional state was determined by the «WAM» method (Well-being, activity and mood). As noted by the authors of the methodology (Barkanova, 2009) the standard for assessing health, activity and mood lies in the range of 5-5.5 points.

It should be noted that when analyzing the functional state, not only the values of its individual indicators are important, but also their ratio and interrelation. In particular, the WAM assessments of a person at rest are usually approximately equal, and as tiredness increases, the ratio between them changes due to a relative decrease in well-being and activity compared to mood.

The analysis of the hiking trip participant's psychoemotional state is presented in Fig. 2. The chart of changes in the assessment of well-being, activity and mood shows that before the start of the hiking trip, youngsters have the result of well-being according to the WAM method in the standard range of 5.4. At the control point $3 \mathrm{~km}$, there is an increase in the indicators of the psychoemotional state of the participants in the pedagogical experiment.
The value of the assessment of well-being, activity and mood is 5.8 points. Most likely, such a reaction of the body of the hiking trip participants is due to the working capacity of all functional systems and shows the sufficiency of the intensity and volume of physical activity. However, at the control points $6 \mathrm{~km}, 9 \mathrm{~km}, 12$ $\mathrm{km}$ and $15 \mathrm{~km}$, there is a gradual decrease in these indicators, and by the end of the hike, the average WAM score among youngsters is 4.9 points. It is important to note that the distance of $15 \mathrm{~km}$ is suitable for controlling the tourist readiness of young men, since their subjective assessment of well-being remained within the normal range.

The correlation between ECG indicators and WAM indicators is direct (an increase in points in the assessment of physical tiredness is associated with a deterioration in the WAM indicators), however, the tightness (strength) of the connection according to the Chaddock scale is assessed as insufficient.

The change in blood pressure among the participants of the hiking trip (Fig. 3) shows that the physical activity provided by the conditions of the pedagogical experiment is appropriate for organizing the test. There are no fluctuations in

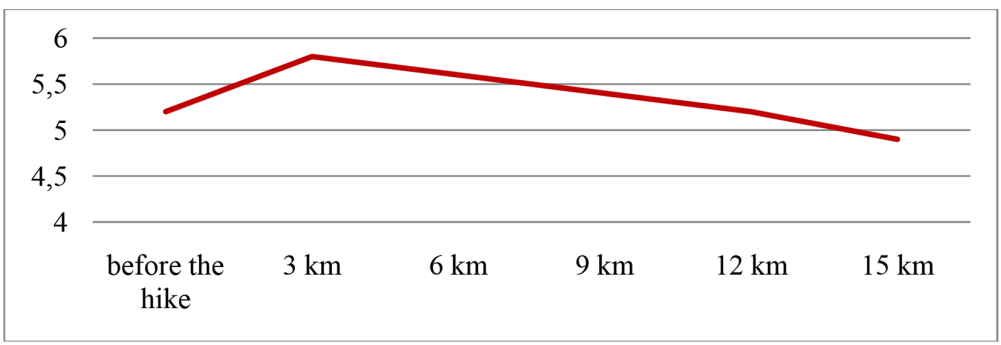

Fig. 2. Indicators of the psychoemotional state of young men during the hiking trip performance (in points) 


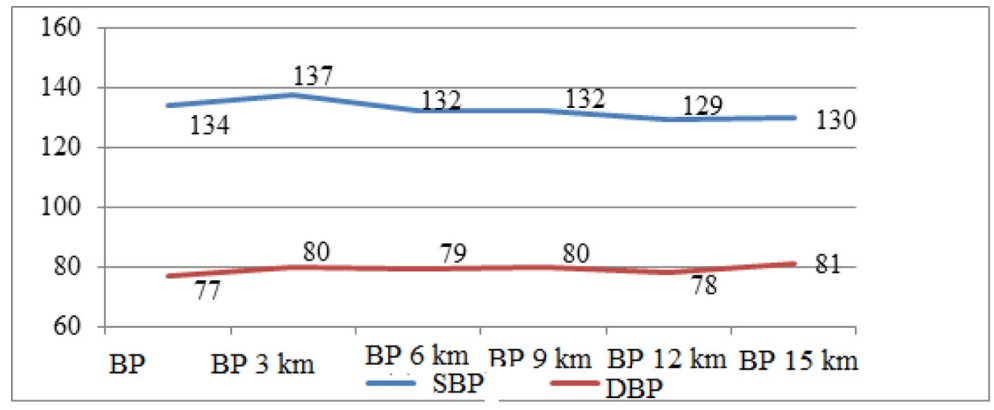

Fig. 3. Blood pressure indicators changes

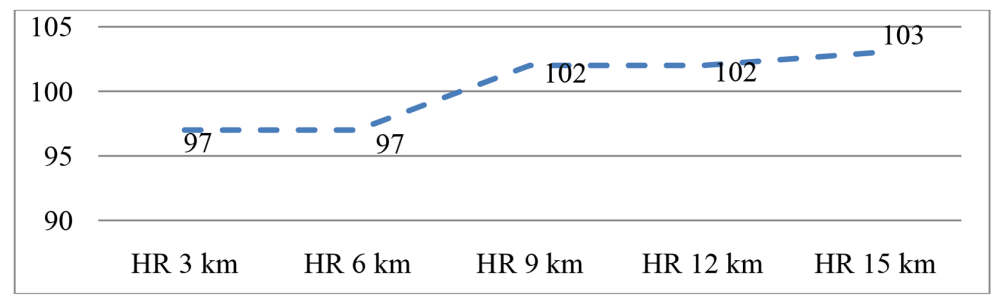

Fig. 4. Participants' heart rate growth dynamics during the hiking trip

the dynamics of the blood pressure indicators of young men (Fig. 4), which confirms the legitimacy of choosing the distance of at least $15 \mathrm{~km}$ for male teenagers of the $6^{\text {th }}$ age group.

Heart rate is the most important physiological indicator of the functional state of the body and the proportionality of the body's response to the proposed physical activity. It is considered that pulse fluctuations under the influence of average physical activity are identical to the standard 130-150 BPM at rest values of 60-80 BPM (for untrained people).

Thus, the rate of heart rate increase when performing physical activities corresponds to an increase by almost 2 times. Fig. 4 shows the heart rate growth dynamics among hiking trip participants. It is clear that no sufficient increase in heart rate is observed. Therefore, the boys at the $15 \mathrm{~km}$ control point demonstrated the highest heart rate values and an increase of $6 \%$. However, the change in heart rate does not have significant differences from the values at the beginning of the hiking trip.

\section{Conclusion}

The analysis of the participants' functional state dynamics in the hiking trip - changes in the heart rate, blood pressure, the degree of tiredness according to the ECG control method, the level of the psychoemotional state of the WAM allowed us to conclude that the distance of 15 $\mathrm{km}$, recommended as the main one for testing at the choice testing of tourist skills «within the GTO sports training program», is optimal for male teenagers of the $6^{\text {th }}$ age group. Therefore, overcoming the distance of $15 \mathrm{~km}$, the body of the participants does not accumulate physical and psychological tiredness, which could affect the performance of the main task of the test - the demonstration of 3-7 tourist skills, depending on the degree. However, the results obtained indicate the possibility of introducing variable conditions in the form of increasing the duration of the tourist distance to $18 \mathrm{~km}$. The final recommendations on the optimal duration of the hiking trip will be made after a simulation experiment and additional research. 


\section{References}

Lubysheva, L.I., Roubaix, M.P. (2019). Prodvizhenie vserossiiskoi programmy podgotovki v oblasti fizichekoi kul'tury i sporta GTO pri pomoshchi nauchnykh i sporivnykh publikatsii v oblasti sotsiologicheskogo analiza [Promotion of the All-Russian physical culture and sports training program GTO by means of scientific and sports periodicals in the aspect of sociological analysis]. In Fizicheskaia kultura: vospitanie, obrazovanie, trenirovka [Physical education: upbringing, education, training], 5, 2-4.

Uvarov, V.A. (2017). O problemakh sushchestbuiushchei programmy podgotovki GTO i osnovnykh napravleniiakh uluchsheniia programmy, vvodimykh 1 ianvaria $2018 \mathrm{~g}$ [About the problems of the existing GTO training program and the main directions of further improvement of the program, introduced from January 1, 2018]. In Gumanitarnoe obrazovanie i nauka v tekhnicheskom vuze: sb. dokladov Vserossiiskoi nauchno-prakticheskoi konferentsii s mezhdunarodny'm uchastiem [Humanitarian education and science at a technical university: Collection of reports of the All-Russian Scientific and Practical Conference with international participation]. Izhevsk, Izhevsk State Technical University named after M.T. Kalashnikov Publ., pp. 893-899.

Matyunina, N.V. (2015). Programma GTO kak normativnaiia baza dlia podgotovki studentov pedgogichekikh vuzov [GTO program as a normative basis of physical training of pedagogical university students]. Bulletin of the Buryat State University, 15, 129-131.

Ginzhul, E.V., Kravchuk, T.A. (2018). Sovremennye aspekty metodichekoi podderzhki dlia vypolneniia programmy podgotovki GTO "Pokhod kak testirovanie turistichekikh navykov [Modern aspects of methodological support for the implementation of the All-Russian training program GTO standard "Hiking to test the tourist skills"]. In Sovershenstvovanie sistemy' fizicheskogo vospitaniia, sportivnoi trenirovki, turizma i ozdorovleniia razlichny`kh kategorii naseleniia: sb. materialov XVII Vserossijskoi nauchno-prakticheskoi konferentsii s mezhdunarodny'm uchastiem [Improving the system of physical education, sports training, tourism and rehabilitation of various categories of the population: collection of materials of the XVII All-Russian Scientific and Practical Conference with international participation], Surgut, Surgut State University Publ., pp. 595-599.

Nikolaev, E.A., Osipov, A.Yu., Nagovitsyn, R.S., Zhuykova, S.E. (2019). Problemy organizatsii i provedeniia turistskogo pokhoda $v$ komplekse testovy $k$ h ispy tanii GTO [Problems of organizing and conducting a camping trip in the complex of test trials of the GTO]. Theory and practice of physical culture, 5, 52.

Nikolaev, E.A., Surikova, N.V., Chuprova, E.D., Gomboev, B.B., Uvarov, V.A. (2020). Justification of Hiking Distance as a Kind of Test Within the All-Russian Physical Education and Sports Training Program "Ready for Labour and Defence" for Girls. Human. Sport. Medicine, S1 (20), 77-83. DOI: 10.14529/ hsm20s110

Isaev, A.P., Kodkin, V.L., Erlich, V.V., Khafizova, A.S. (2017). Vysokotochnaia electrokardiografiia dlia otsenki urovnya zdorov'ia i funktsional'noi podgotovki sportsmenov [Highly accurate electrocardiography to assess the level of public health and functional fitness of athletes]. In Materialy XXIII sezda Fiziologicheskogo obshchestva im. I.P. Pavlova s mezhdunarodnym uchastiem [Materials of the XXIII Congress of the Physiological Society of I.P. Pavlov with international participation], 2051-2052.

Zavyalov, A.I. (1984). Klassifikatsiia izmeninenii EKG [Classification of ECG changes]. In Sportivnaia borba: Ezhegodnik [Wrestling: Yearbook]. Moscow, 66-69.

Barkanova, O.V. (2009). Metodiki diagnostiki emotsionalnoi sfery: psikhologicheskii praktikum. Seriia: Biblioteka aktualnoi psikhologii. Vypusk 2 [Diagnostic techniques for the emotional sphere: psychological workshop. Series: Library of actual psychology. Issue 2]. Krasnoyarsk, Litera-print Publ., 237 p. 